\title{
ANALISIS PRIORITAS PENGELOLAAN KAWASAN KONSERVASI PERAIRAN PULAU AY-RHUN, PROVINSI MALUKU
}

\section{ANALYSIS OF MANAGEMENT PRIORITY ON AY-RHUN MARINE PROTECTED AREA, MALUKU PROVINCE}

\author{
Ervien Juliyanto $^{1 *}$, Zairion ${ }^{2,3}$, Majariana Krisanti ${ }^{2}$ dan Handoko Adi Susanto $^{2}$ \\ ${ }^{1}$ Program Studi Pengelolaan Sumberdaya Pesisir dan Lautan, FPIK-IPB, Bogor, 16680 \\ ${ }^{2}$ Departemen Manajemen Sumberdaya Perairan, FPIK-IPB, Bogor, 16680 \\ ${ }^{3}$ Pusat Kajian Sumberdaya Pesisir dan Lautan, Baranangsiang, IPB, Bogor, 16143 \\ *E-mail: ervienkkp@gmail.com
}

\begin{abstract}
Management planning prioritization is critical as a reference for managers when they try to improve the management effectiveness of marine protected areas. The objective of this study is to analyze the prioritization of Ay-Rhun MPA's management planning using the Analytic Network Process. Problems and solutions in determining management priorities are clustered into four categories: ecology, economy, social, and institutional, and inside each cluster is sub-clusters based on the results of Focus Group Discussion. The results show that the main problem of Ay-Rhun MPA management is the ecology cluster. The sub-cluster analysis results showed that management problems should be addressed as priorities are: (1) the lack of human resource in terms of capacity and quantity; (2) the lack of understanding in conservation efforts; (3) price instability in fishery productions; (4) sand and coral mining for construction materials. Sub-cluster in a cluster could affect other elements in the same cluster, and it could also affect elements on different clusters. Therefore, recommendation strategies that should be prioritized to improve management effectiveness of Ay-Rhun MPA are (1) optimization of resource use based on carrying capacity, with the value of 0.6137 ; (2) MPA zonation design, with the value of 0.5484 ; (3) MPA management policy design, with the value of 0.5308; and (4) socialization regarding conservation efforts and understanding, with the value of 0.4680 .
\end{abstract}

Keywords: ANP, decision making, management strategy, MPA

ABSTRAK
Prioritas perencanaan sangat penting ditentukan untuk menjadi acuan pengelola dalam meningkatkan efektivitas pengelolaan kawasan konservasi perairan. Penelitian ini bertujuan untuk menganalisis prioritas perencanaan pengelolaan kawasan konservasi perairan daerah (KKPD) Pulau Ay-Rhun menggunakan metode Jejaring Analitik (Analytic Network Process, ANP). Permasalahan dan solusi dalam penentuan prioritas pengelolaan ini dikelompokkan menjadi empat, yakni: cluster ekologi, ekonomi, sosial, dan kelembagaan dengan masing-masing sub-cluster berdasarkan hasil diskusi kelompok terfokus (Focus Group Discussion, FGD). Hasil analisis menunjukan bahwa masalah utama kawasan konservasi perairan Pulau Ay-Rhun adalah cluster ekologi. Sementara hasil analisis sub-cluster menunjukan bahwa permasalahan prioritas pengelolaan adalah: (1) cluster kelembagaan berupa kurangnya kapasitas dan kuantitas SDM dengan nilai 0,6711 ; (2) cluster sosial berupa kurangnya pemahaman terkait konservasi dengan nilai 0,6340 ; (3) cluster ekonomi berupa ketidakstabilan harga jual hasil perikanan dengan nilai 0,5684 ; (4) cluster ekologi berupa penambangan pasir dan karang untuk material bangunan dengan nilai 0,4614. Mengingat sub-cluster suatu cluster dapat mempengaruhi elemen lain dalam cluster yang sama dan dapat pula mempengaruhi elemen pada cluster yang berbeda, maka rekomendasi prioritas strategi pengelolaan dalam meningkatkan efektifitas kawasan konservasi perairan Ay-Rhun adalah: (1) cluster ekonomi berupa optimalisasi pemanfaatan sesuai daya dukung dengan nilai 0,6137; (2) cluster ekologi berupa pembentukan zonasi dengan nilai 0,5484 ; (3) cluster kelembagaan berupa penyusunan kebijakan pengelolaan dengan nilai 0,5308; dan (4) cluster sosial berupa sosialisasi mengenai konservasi dengan nilai 0,4680 .

Kata kunci: ANP, Decision making, KKPD, strategi pengelolaan 


\section{PENDAHULUAN}

Kawasan konservasi perairan dibentuk untuk mencapai berbagai tujuan, di antaranya adalah untuk melindungi spesies dan habitat laut, melestarikan keanekaragaman hayati laut, memulihkan stok perikanan, mengelola kegiatan pariwisata dan meminimalkan konflik di antara pengguna sumberdaya yang beragam (Pomeroy et al., 2004). Kawasan konservasi perairan adalah area dimana aktivitas manusia dibatasi untuk mengelola dan melindungi laut dan sumber daya pesisir terhadap ancaman seperti eksploitasi berlebihan dan kerusakan ekologis (Cleguer et al., 2015). Kinerja suatu kawasan konservasi perairan sangat bergantung kepada banyak elemen seperti desain, implementasi pengelolaan dan karakteristik daerah (Barnes et al., 2016). Suatu daerah dijadikan kawasan konservasi perairan memiliki efek ekologi yang positif (Edgar et $a l ., 2014$ ) seperti meningkatnya ke-limpahan spesies dan peningkatan kualitas habitat serta efek sosial ekonomi yang signifikan untuk masyarakat pesisir (Rodríguez-Rodríguez et al., 2015; Santo, 2013). Pengelolaan kawasan konservasi perairan dinyatakan berhasil apabila dapat mencapai tujuan yang ditetapkan (Agardy et al., 2011; Fox et al., 2012).

Hal yang sama juga terhadap beberapa kawasan konservasi perairan yang telah dibentuk di Indonesia, namun pada rencana pengelolaannya hanya sebatas dokumen dan implementasinya menemui kesulitan. Hal ini disebabkan karena kurang fokusnya terhadap prioritas pengelolaan-nya. Angulo-Valdes dan Hatcher (2010) menyatakan bahwa pengelolaan kawasan konservasi yang efektif terus menjadi tantangan bagi para pengelola dan peneliti. Kutipan dalam MPA News (2012) dan Susanto et al. (2015) menyatakan bahwa kawasan konservasi perairan hanya sebatas "Paper park" yaitu kawasan konservasi perairan di atas kertas, memiliki peta dan kebijakan, namun tidak menunjukkan pengelolaan yang efektif. Oleh karena itu, suatu tantangan yang berat bagi peneliti dan pengelola di Indonesia dalam merumuskan dan mengimplementasikan pengelolaan kawasan konservasi perairan secara efektif.

Kawasan konservasi perairan Pulau Ay-Rhun, Kecamatan Banda Tengah, Provinsi Maluku merupakan salah satu Kawasan Konservasi Perairan Daerah (KKPD). Kawasan konservasi perairan tersebut diinisiasi oleh masyarakat dan mendapatkan pendampingan dalam prosesnya oleh Coral Triangle Center (CTC) pada tahun 2014 serta diusulkan kepada Dinas Kelautan dan Perikanan (DKP) Provinsi Maluku (sesuai amanat UU No. 23/2014 tentang pemerintahan daerah). Berdasarkan usulan tersebut, kawasan konservasi ini sudah ditetapkan pencadangannya sebagai Taman Wisata Perairan (TWP) seluas 47.968,74 Ha melalui Surat Keputusan Gubernur Provinsi Maluku No. 388 tahun 2016 tentang Pencadangan Kawasan Konservasi Perairan Pulau AyRhun, Kecamatan Banda Tengah, Provinsi Maluku (Pemda, 2016). Kawasan konservasi tersebut harus berfungsi untuk melindungi seluruh ekosistem pesisir di pulau kecil dan laut di sekitarnya yang memerlukan sebuah rencana prioritas pengelolaan yang adaptif dan berkelanjutan. Perencanaan tersebut merupakan suatu alat manajemen yang dapat membantu pengelola kawasan konservasi perairan untuk lebih fokus dalam mengimplementasikan, termasuk mengambil kebijakan sesuai dengan kewenangan yang ada. Pengelolaan me-rupakan produk dari suatu proses perencanaan yang diikuti dengan implementasi yang dilengkapi dengan pelaksanaan pemantauan serta evaluasi secara berkelanjutan untuk menguji keefektifan dari sebuah rencana pengelolaan. Sumberdaya, keterampilan dan sistem organisasi sangat diperlukan untuk memastikan keberhasilan dalam perencanaan pengelolaan kawasan konservasi perairan. 
Tantangan terbesar dalam pengelolaan kawasan konservasi perairan Pulau Ay-Rhun adalah bagaimana kawasan konservasi tersebut dapat terkelola dengan baik dan dapat terukur tingkat pengelolaannya melalui sebuah prioritas pengelolaan yang baik pula. Agardy (1998) menyatakan bahwa penetapan tujuan pembentukan kawasan konservasi perairan sangat penting untuk menentukan tujuan dari pengelolaan, merancang secara efektif dan memiliki target konservasi dan terukur untuk menilai kemajuan pengelolaan untuk mencapai tujuan yang diinginkan. Berdasarkan hal tersebut di atas, maka tujuan penelitian ini adalah untuk menganalisis prioritas pengelolaan dengan metode Analitic Network Process (ANP). Hasil analisis ini digunakan sebagai input upaya pe-ningkatan efektivitas kawasan konservasi perairan Pulau Ay-Rhun untuk mempertahankan sumberdaya pesisir agar dapat dikelola secara adaptif dan dapat dimanfaatkan secara berkelanjutan.

\section{METODE PENELITIAN}

\subsection{Waktu dan Tempat}

Penelitian ini dilaksanakan pada bulan Agustus hingga November 2018 di kawasan konservasi perairan Pulau AyRhun, Kabupaten Maluku Tengah, Provinsi Maluku. Kawasan konservasi ini terletak di Kepulauan Banda, tepatnya di busur dalam laut Banda (Banda Sea Inner Arc). Batasan kawasan konservasi ini adalah pada koordinat $04^{\circ} 27^{\prime} 00^{\prime \prime}$ LS - 129 $36^{\prime} 00^{\prime \prime}$ BT

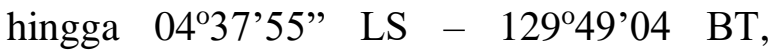
sehingga luas area kajian adalah 47.968,74 Ha (Gambar 1).

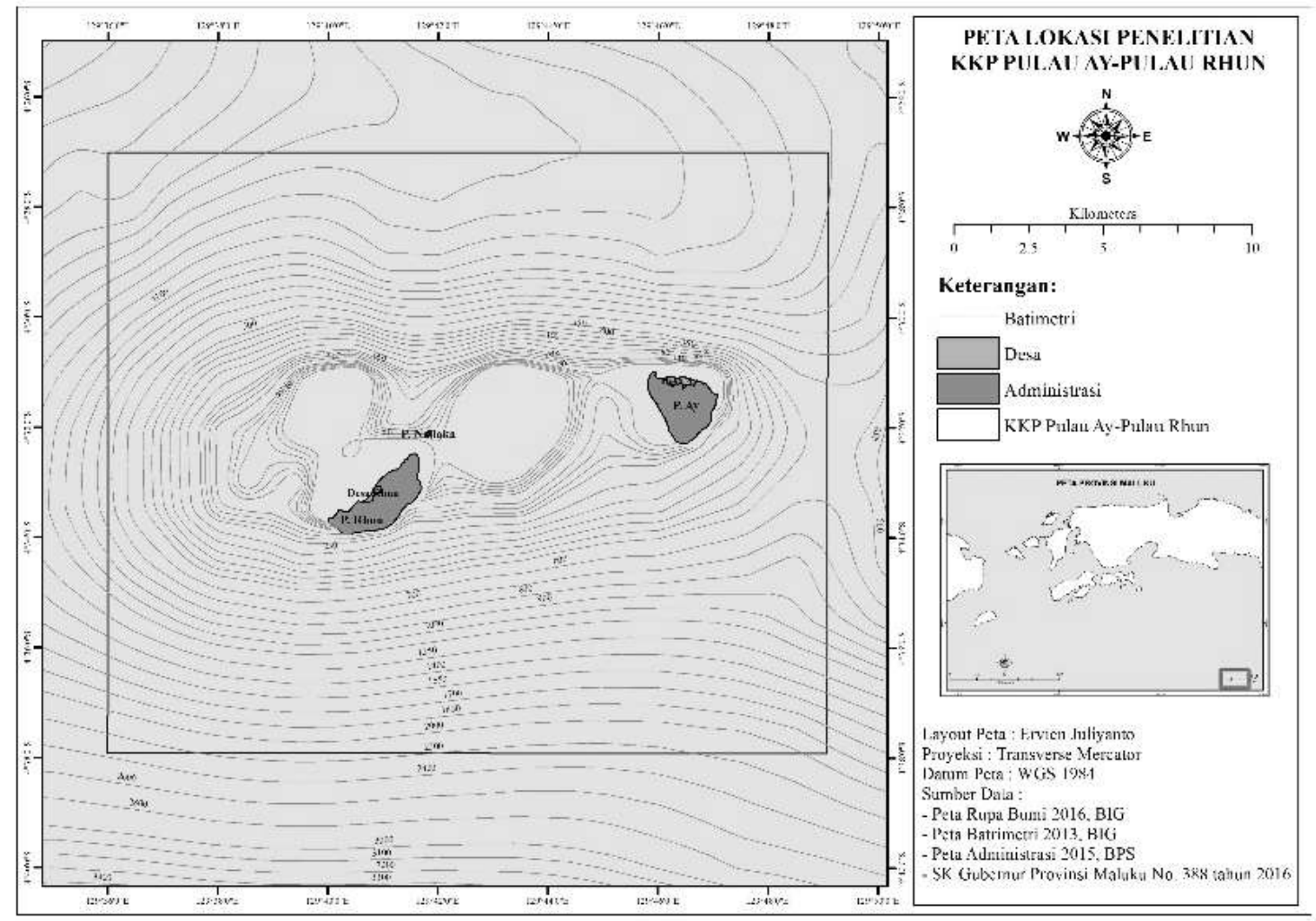

Gambar 1. Area kajian kawasan konservasi perairan Pulau Ay-Pulau Rhun. 


\subsection{Pengumpulan Data dan Rancangan Penelitian}

Penelitian ini merupakan penelitian analisis kualitatif-kuantitatif guna menghasilkan suatu nilai atau pandangan yang diwakili para pakar dan praktisi konservasi menggunakan metode jejaring analitik (ANP). Pendekatan berdasarkan pendapat pakar dapat digunakan untuk mencapai pengelolaan yang adaptif (Mittermeier et al., 1995). Metode ANP tersebut digunakan untuk menentukan skala prioritas relatif yang didapatkan dari angka mutlak berdasarkan penilaian individual (Saaty, 2005).

Analisis prioritas pengelolaan dilakukan melalui wawancara mendalam dari para ahli yang berkompeten di bidang perikanan dan kelautan khususnya bidang kawasan konservasi perairan. Wawancara dilakukan dalam dua tahap, yaitu: (1) Responden melalui FGD ke masyarakat diminta untuk menjelaskan terkait isu dan permasalahan yang terjadi di kawasan konservasi perairan berdasarkan cluster ekologi, sosial, ekonomi dan kelembagaan.
Stakeholder lokal yang terlibat dalam desain perencanaan kawasan konservasi perairan cenderung memiliki tingkat pengetahuan lokal yang dapat memberikan sumber bukti dan informasi berharga untuk kawasan konservasi perairan (Cook et al., 2014); (2) Wawancara kedua dilakukan kepada para ahli untuk mendapatkan bobot penilaian menggunakan matriks per-bandingan berpasangan; dan (3) verifikasi hasil kepada pakar.

Sub-cluster di dalam setiap cluster diberi penilaian skala prioritas oleh para ahli. Ada 2 (dua) kontrol yang perlu diperhatikan dalam memodelkan sistem yang hendak diketahui bobotnya yaitu: (1) Kontrol hierarki yang menunjukkan keterkaitan cluster dan sub-cluster; dan (2) Kontrol keterkaitan yang menunjukkan adanya saling keterkaitan antar cluster. Untuk menentukan tingkat pengaruh suatu cluster dalam Analytic Network Process (ANP) digunakan perangkat lunak komputer super decision versi 2.6. Rancangan tahapan dalam teknik ANP disajikan pada Gambar 2.

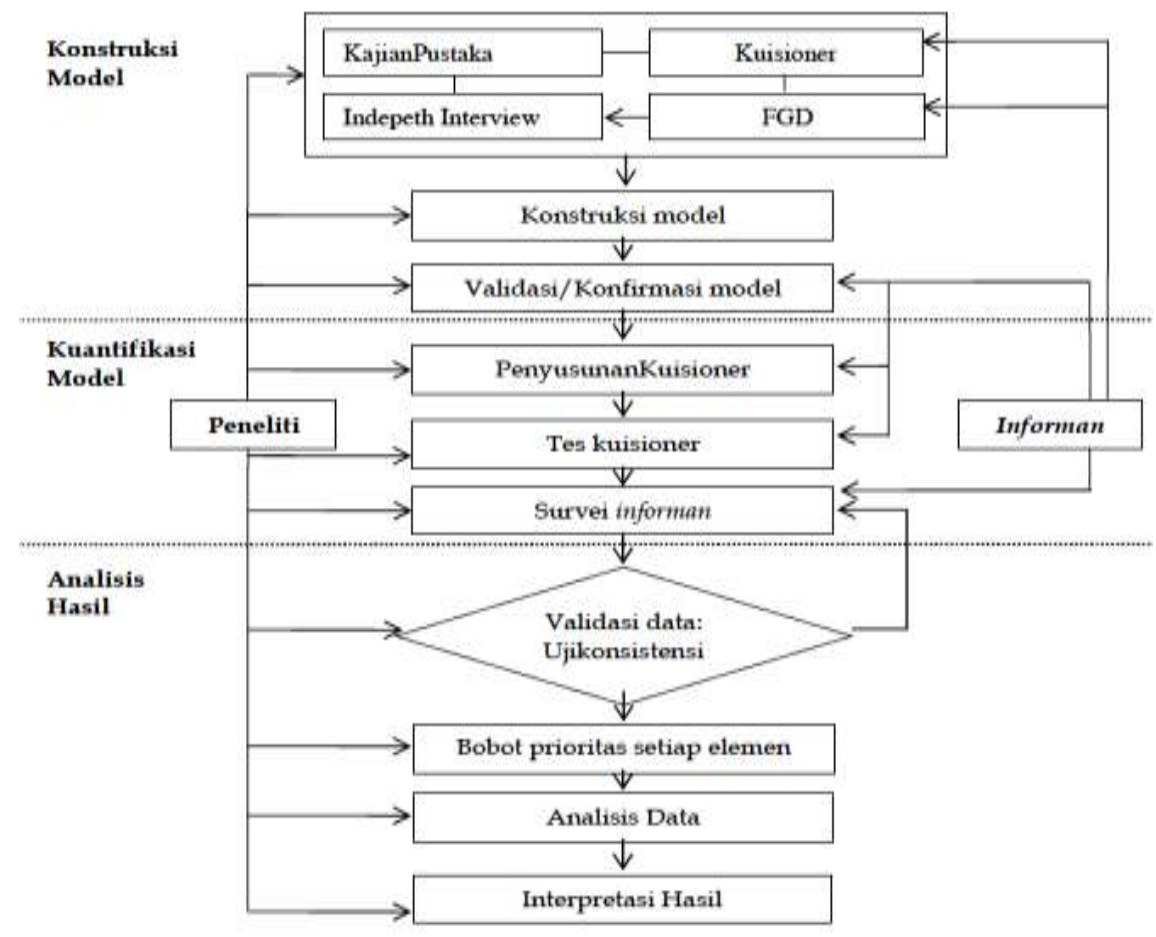

Gambar 2. Tahapan analytic network process (ascarya, 2010). 
Rancangan permasalahan dan solusi dalam penentuan prioritas pengelolaan kawasan konservasi perairan Pulau Ay-Rhun dibagi menjadi 4 (empat) cluster yang terdiri dari aspek ekologi, sosial, ekonomi, dan kelembagaan. Cluster tersebut secara keseluruhan dikelompokkan menjadi cluster masalah, solusi, dan prioritas. Adapun subcluster dari masalah yang diperoleh melalui FGD untuk mendapatkan permasalahan riil di lapangan dalam hal penentuan prioritas pengelolaan kawasan konservasi perairan Pulau Ay-Rhun di antaranya adalah:

1. Masalah ekologi terdiri atas: (1) penurunan luas ekosistem; (2) sampah pemukiman; dan (3) pasir dan karang untuk bangunan.

2. Masalah sosial terdiri atas: (1) kurangnya koordinasi pengelolaan konservasi; (2) kurang pemahaman terkait konservasi; dan (3) kurangnya peran adat dalam pengelolaan kawasan konservasi.

3. Masalah ekonomi terdiri atas: (1) SDA belum dimanfaatkan secara optimal; (2) kurang pengembangan produk olahan; dan (3) ketidakstabilan harga jual hasil perikanan.

4. Masalah kelembagaan terdiri atas: (1) kurangnya kapasitas dan kuantitas SDM;

(2) kurang koordinasi antar lembaga; dan

(3) terbatasnya pendanaan.

Hasil studi literatur, FGD dan wawancara mendalam kepada pakar yang memahami dan menguasai masalah secara komprehensif tentang permasalahan dan solusinya, diperoleh uraian solusi dari permasalahan-permasalahan tersebut di atas sebagai berikut:

1. Solusi ekologi meliputi: (1) pembentukan zonasi; (2) pengendalian dan pengawasan; dan (3) pengelolaan sampah.

2. Solusi sosial meliputi: (1) revitalisasi dan capacity building; (2) sosialisasi mengenai konservasi; dan (3) meningkatkan koordinasi antar lembaga.

3. Solusi ekonomi meliputi: (1) introduksi mata pencaharian alternatif; optimalisasi pemanfaatan sesuai daya dukung; dan (3) strandarisasi harga jual produk perikanan.

4. Solusi kelembagaan meliputi: penyusunan kebijakan pengelolaan; (2) peningkatan kapasitas dan kuantitas SDM; (3) pembentukan jejaring dan kemitraan; dan (4) identifikasi alternatif pendanaan.

Identifikasi masalah dan solusi untuk menentukan output strategi prioritas pengelolaan kawasan konservasi perairan Pulau Ay-Rhun yang telah dikemukakan di atas, selanjutnya digunakan untuk membentuk jaringan struktur ANP (Gambar $3)$.

\subsection{Analisis Data}

Alat analisis data yang digunakan adalah metode ANP dengan bantuan software Super Decision versi 2.6. Metode tersebut digunakan untuk menentukan skala prioritas relatif yang didapatkan dari angka mutlak berdasarkan penilaian individual (Saaty, 2005). Tahapan analisis data meliputi:

1) Penyusunan struktur jaringan (model construction) dilakukan berdasarkan kajian literatur, baik secara teori maupun empiris dan dilaksanakan melalui indepth interview untuk mengkaji informasi yang lebih dalam serta memperoleh permasalahan yang sebenarnya di lapangan;

2) Pembobotan oleh ahli, yaitu cluster yang sudah disusun kemudian dibuat perbandingannya dalam super matriks menggunakan metode pembobotan para ahli untuk membandingkan sebuah cluster dengan cluster lainnya.

3) Sintesis ANP.

Data hasil penilaian kemudian dikumpulkan dan diinput ke dalam software super decision untuk diproses guna menghasilkan output berbentuk supermatriks kemudian disintesis menjadi prioritas. Hasil dari setiap responden akan diinput pada jaringan ANP tersendiri (Ascarya, 2010). Adapun sintesis dan analisis data, pada tahap ini terbagi menjadi dua, yaitu: 


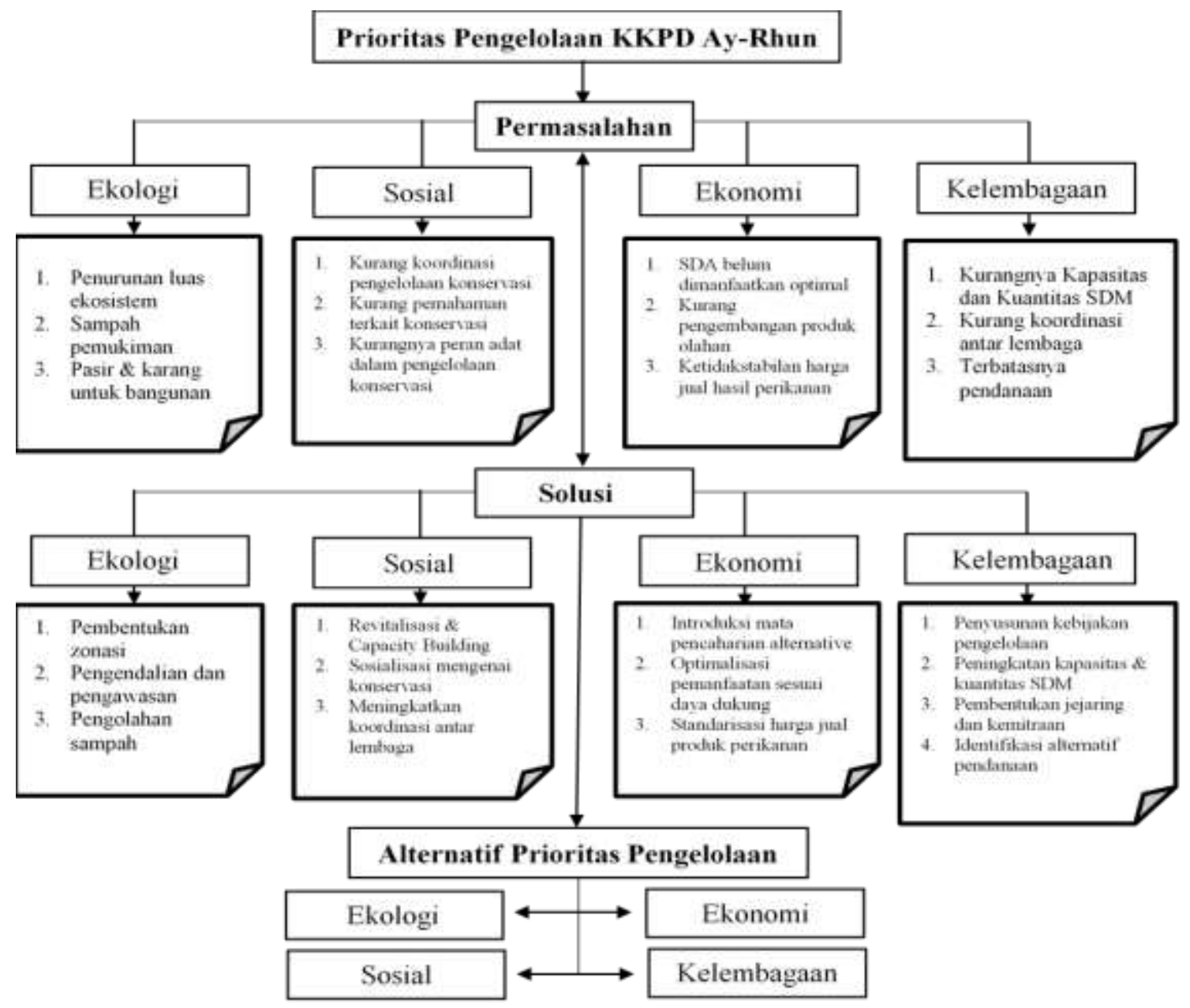

Gambar 3. Struktur jaringan (model construction) prioritas pengelolaan KKPD Ay-Rhun.

a. Geometric Mean, dilakukan untuk mengetahui hasil penilaian individu dari para pakar dan menentukan hasil pendapat pada satu kelompok dilakukan penilaian dengan menghitung nilai rata-rata geometrik atau geometric mean (Saaty dan Vargas, 2006). Pertanyaan berupa perbandingan (Pairwise comparison) dari responden akan dikombinasikan sehingga membentuk suatu konsensus. Geometric mean merupakan jenis penghitungan ratarata yang menunjukkan tendensi atau nilai tertentu dan ditentukan dengan formula berikut:

$\left(\Pi_{i}^{n}=1_{i}\right)^{\frac{1}{n}}=\sqrt[n]{a_{1}, a_{2}, \ldots a_{n}}$
Perhitungan geometric mean dilakukan untuk memberikan pendekatan rata-rata yang lebih baik karena bisa mengeliminasi deviasi yang terjadi untuk data-data yang didapat dari penilaian responden dalam kuisioner.

b. Sintesis dalam perhitungan metode ANP dilakukan dengan rater agreement, yakni ukuran yang menunjukan tingkat kesesuaian (persetujuan) para responden $\left(\mathrm{R}_{1}-\mathrm{R}_{\mathrm{n}}\right)$ terhadap suatu masalah dalam suatu cluster. Alat yang digunakan untuk mengukur rater agreement adalah Kendall's Coefficient of Concordance (W; $0<\mathrm{W} \leq 1)$. Tahapan untuk menghitung koefisien Kendal's (W), adalah: 
Menghitung total jumlah perankingan tiap masing-masing cluster :

$$
\mathrm{Xa}=\left(R_{1}+R_{2}+\ldots+R_{n}\right)
$$

Menghitung nilai rata-rata (U) dari total ranking tiap cluster :

$\mathrm{U}=\frac{x_{a}+x_{b}+\ldots+x_{z}}{z}$

Menghitung nilai jumlah kuadrat deviasi (S), dihitung dengan formula :

$$
\mathrm{S}=\left(R_{1}-\mathrm{u}\right)^{2}+\left(R_{2}-\mathrm{u}\right)^{2}+\ldots+\left(R_{n}-\mathrm{u}\right)^{2}
$$

Menghitung nilai maksimal kuadrat deviasi (Max S), dihitung dengan formula :

$$
\operatorname{Max} \mathrm{S}=(\mathrm{n}-\mathrm{u})^{2}+(2 \mathrm{n}-\mathrm{u})^{2}+\ldots+(\mathrm{Zn}-\mathrm{u})^{2} .
$$

Langkah terakhir menentukan nilai Kendall's W dalam perhitungan Rater of Agreement yaitu dengan formula :

$\mathrm{W}=\frac{\mathrm{s}}{\mathrm{Max} \mathrm{S}}$

Keterangan:

$\mathrm{X}=$ Jumlah tiap cluster

$\mathrm{R}=$ Bobot ranking tiap responden

$\mathrm{n}=$ Jumlah responden

$\mathrm{z} \quad=$ Banyaknya cluster

$\mathrm{U}=$ Rata-rata nilai total pada tiap cluster

$\mathrm{S}=$ Nilai jumlah kuadrat deviasi

Max S = Nilai maksimal kuadrat deviasi

$\mathrm{W}=$ Rater of Agreement

Output yang akan dicapai secara statistik akan dihasilkan penilaian dari para pakar dan praktisi terkait masalah dan solusi dalam rangka mengidentifikasi prioritas pengelolaan kawasan konservasi perairan Pulau Ay-Rhun. Hal ini didukung oleh rater agreement dengan nilai tertinggi Kendall "s Coefficient of Concordance $\mathrm{W}=1$ (W=100\%), menunjukan tingkat kesepahaman yang sempurna dari setiap pakar dalam menentukan prioritas pengelolaan
(Ascarya, 2011). Akurasi tingkat kesepakatan para responden terhadap penentuan prioritas strategi dan cluster yang dipilih dapat diuji dengan menggunakan analisis rater agreement berdasarkan koefisien Kendall (W). Nilai koefisien Kendall (W) dihitung dengan menggunakan bantuan program perangkat lunak pengolahan data statistik "Microsoft excel".

Output secara keseluruhan memiliki dua nilai yaitu nilai normalized by cluster dan nilai limiting. Nilai normalized by cluster adalah nilai prioritas pada setiap satu cluster yang bernilai total satu atau seratus persen jika dijumlah dalam satu cluster. Analisis di setiap cluster digunakan nilai limiting karena pada dasarnya urutan prioritas pada pilihan alternatif pada satu cluster akan menghasilkan urutan yang sama baik menggunakan nilai normalized by cluster maupun menggunakan nilai limiting. Rusydiana dan Devi (2013) menyatakan bahwa Analysis Network Process memberikan peluang bahwa elemen dalam suatu cluster dapat mempengaruhi elemen lain dalam cluster yang sama (inner dependence), dan dapat pula mempengaruhi elemen pada cluster yang lain (outer dependence) dengan memperhatikan setiap cluster. Hal tersebut menunjukkan bahwa permasalahan dalam sebuah cluster dapat diselesaikan melalui cluster lainnya.

\section{HASIL DAN PEMBAHASAN}

\subsection{Hasil}

Cluster masalah ekologi (nilai sebesar 0,5396) menjadi prioritas dan sebagai kendala utama dalam pengembangan pengelolaan kawasan konservasi perairan Pulau Ay-Rhun. Masalah selanjutnya diikuti oleh cluster masalah ekonomi (0,2101), masalah sosial $(0,1691)$, dan kelembagaan $(0,0812)$. Hasil perolehan rater agreement untuk cluster masalah menunjukkan nilai $\mathrm{W}=0,808$, yang berarti $80,8 \%$ responden sepakat bahwa masalah prioritas pengelolaan 
kawasan konservasi perairan Pulau Ay-Rhun adalah masalah ekologi (Gambar 4 a).

Sejalan dengan cluster masalah, cluster solusi yang menjadi prioritas dalam pengelolaan kawasan konservasi perairan Pulau Ay-Rhun adalah aspek ekologi (0,6046), selanjutnya diikuti oleh solusi aspek ekonomi $(0,2061)$, kelembagaan $(0,0954)$, dan yang menempati urutan terakhir adalah aspek sosial $(0,0939)$. Hasil perolehan rater agreement untuk cluster solusi menunjukkan nilai $\mathrm{W}=0,712$, yang berarti $71,2 \%$ responden sepakat bahwa solusi prioritas pengelolaan kawasan konservasi perairan Pulau Ay-Rhun adalah pada aspek ekologi (Gambar 4b).

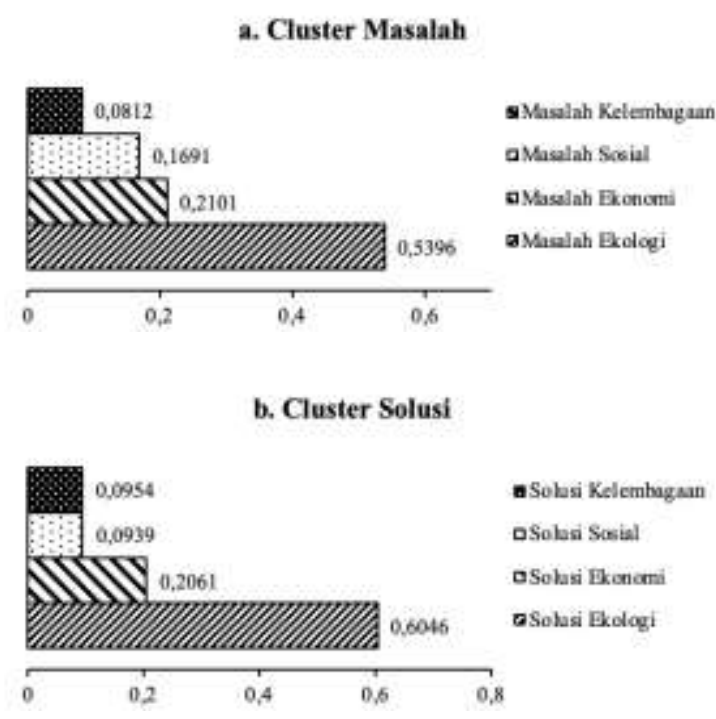

Gambar 4. Cluster masalah dan solusi: a. Cluster Masalah; b. Cluster Solusi.

Nilai rater agreement yang diperoleh secara keseluruhan (nilai limiting) untuk setiap sub-cluster masalah dan solusi adalah $\mathrm{W}=0,7644 \quad(\mathrm{~W}=76,44 \%), \quad$ menunjukkan bahwa penilaian atau pendapat dari para responden memiliki kesesuaian yang tinggi. Masalah prioritas pada sub-cluster aspek ekologi adalah penambangan pasir dan karang untuk material bangunan dengan nilai 0,4614 , sedangkan masalah pada sub-cluster aspek ekonomi adalah ketidakstabilan harga jual hasil perikanan dengan nilai 0,5684 (Gambar 5a dan 5b). Masalah pada subcluster aspek sosial adalah kurangnya pemahaman masyarakat terkait konservasi sebesar 0,6340 dan sub-cluster aspek kelembagaan adalah masalah terkait kurangnya kapasitas dan kuantitas SDM dengan nilai 0,6711 (Gambar 5c dan 5d).

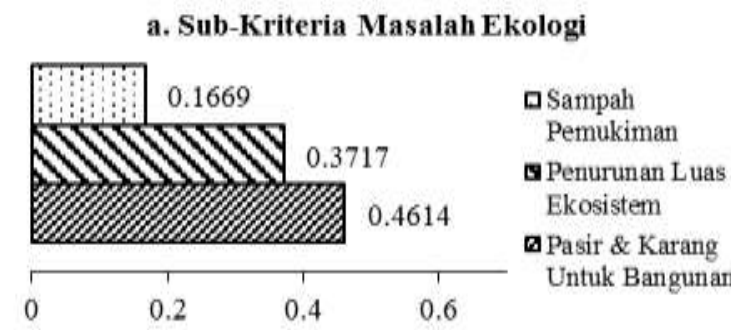

b. Sub-Kriteria Masalah Ekonomi
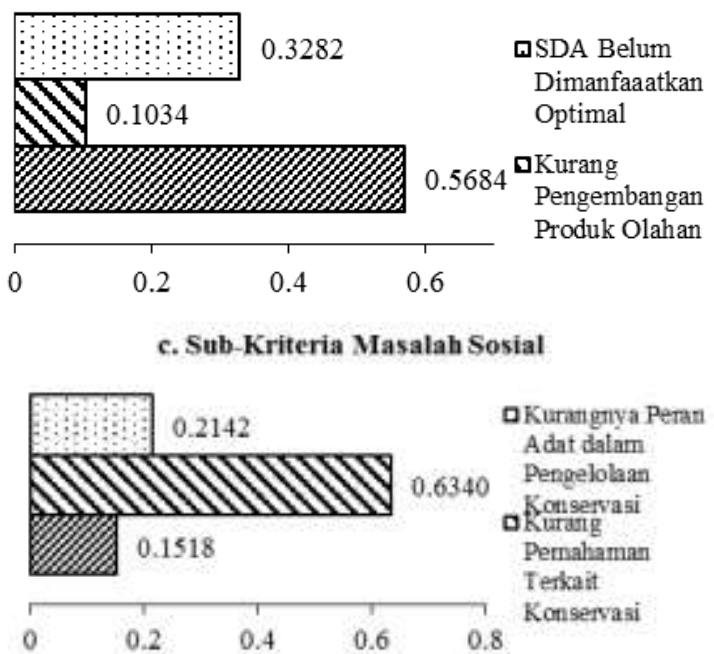

d. Sub-Kriteria Masalah Kelembagaan

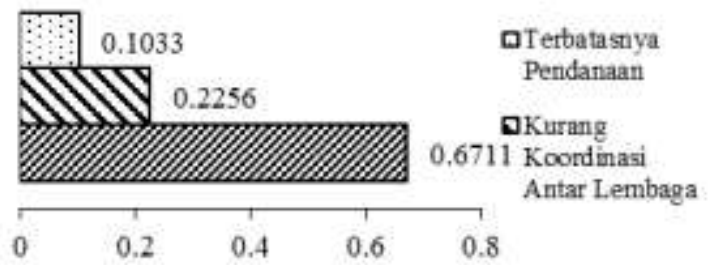

Gambar 5. Sub-cluster masalah prioritas pengelolaan kawasan konservasi perairan Pulau Ay-Rhun. a. Subcluster masalah ekologi; b. Subcluster masalah ekonomi; c. Subcluster masalah sosial; dan d.

Sub-cluster masalah kelembagaan. 
a. Sub-Kriteria Solusi Ekologi

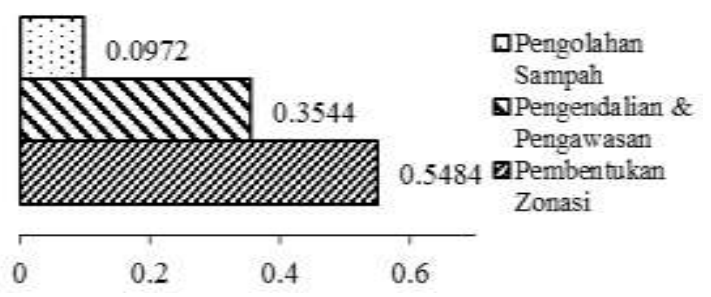

b. Sub-Kriteria Solusi Ekonomi

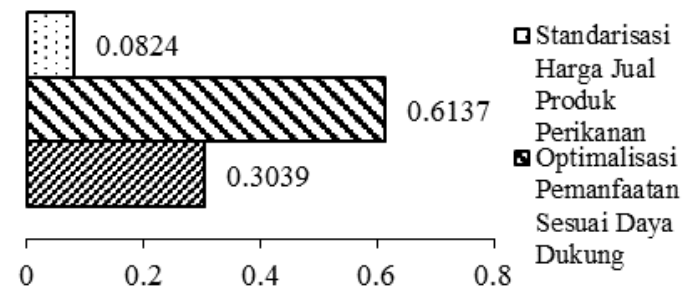

c. Sub-Kriteria Solnsi Sosial

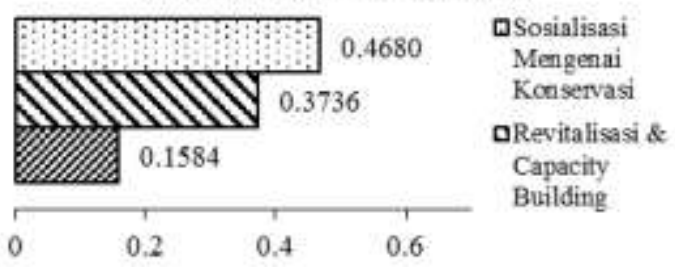

d. Sub-Kriteria Solusi Kelembagaan

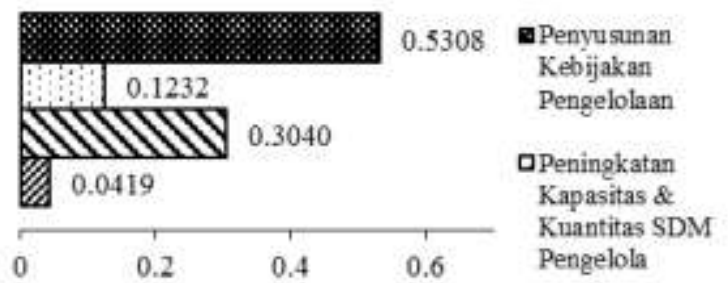

Gambar 6. Sub-cluster solusi prioritas pengelolaan Kawasan Konservasi Perairan Pulau Ay-Rhun: a. subcluster solusi ekologi; b. subcluster solusi ekonomi; c. subcluster solusi sosial; dan d. subcluster solusi kelembagaan.

Solusi prioritas pada sub-cluster aspek ekologi adalah masalah pembentukan zonasi dengan nilai 0,5484 (Gambar 6a)., Solusi pada Sub-cluster aspek ekonomi adalah optimalisasi pemanfaatan sesuai dengan daya dukung dengan nilai 0,6137 (Gambar 6b). Sementara itu, solusi subcluster aspek sosial adalah sosialisasi mengenai konservasi sebesar 0,4680 (Gambar 6c) dan Sub-cluster aspek kelembagaan adalah penyusunan kebijakan pengelolaan dengan nilai 0,5308 (Gambar 6d).

\subsection{Pembahasan}

Salah satu kelemahan terbesar dalam penyusunan rencana pengelolaan kawasan konservasi perairan adalah ketidak-mampuan melaksanakan perencanaan dengan baik, terutama terkait dengan identifikasi masalah dan alternatif solusinya serta menentukan prioritas dalam pengelolaan. Cluster masalah dan solusi dari para pakar menunjukan bahwa masalah yang paling banyak dihadapi dalam menentukan prioritas pengelolaan kawasan konservasi perairan Pulau Ay-Rhun adalah masalah ekologi. Masalah ekologi ini mempunyai nilai tingkat kesepahaman para pakar sebesar 0,5396 dengan rater of agreement $(\mathrm{W})=0,808$ atau $\mathrm{W}=80,8 \%$, sedangkan solusi ekologi dengan nilai 0,6046 dengan nilai $\mathrm{W}=0,712$ atau $\mathrm{W}=71,2 \%$. Hal ini menunjukkan bahwa aspek ekologi harus diutamakan dibandingkan aspek sosial, ekonomi, dan kelembagaan. Apabila aspek permasalahan pengelolaan ekologi dapat diatasi, maka dapat mempengaruhi aspekaspek lainnya. Nilai rater agreement (W) yang diperoleh untuk masing-masing cluster masalah tergolong tinggi $(>70 \%)$, yang menunjukkan jawaban dari para pakar memiliki tingkat kesepahaman yang cukup besar bahwa masalah prioritas pengelolaan kawasan konservasi perairan Pulau Ay-Rhun adalah masalah ekologi.

$$
\text { Strategi prioritas pengelolaan }
$$

kawasan konservasi perairan Pulau Ay-Rhun ditentukan berdasarkan hasil analisis keseluruhan sub-cluster masalah. Hasil rater agreement keseluruhan sub-cluster diperoleh nilai $\mathrm{W}=0,7644$ atau $\mathrm{W}=76,44 \%$. Nilai yang demikian menunjukkan bahwa tingkat kesepahaman yang tinggi dalam menilai 
prioritas pengelolaan kawasan konservasi perairan Pulau Ay-Rhun. Untuk melihat kontribusi masing-masing elemen masalah pada setiap aspek dalam upaya penyusunan prioritas kawasan konservasi perairan Pulau Ay-Rhun, maka disintesis dengan mengkombinasikan keseluruhan sub-cluster masalah (Gambar 7). Hasil kombinasi seluruh aspek permasalahan, para pakar sepakat bahwa permasalahan di dalam pengelolaan kawasan konservasi perairan Pulau Ay-Rhun adalah: Pertama, kurangnya kapasitas dan kuantitas SDM dengan nilai 0,6711 (kelembagaan). Hal ini menunjukkan bahwa Cabang Dinas Gugus Pulau 6 DKP Provinsi Maluku yang baru dibentuk memerlukan kelengkapan personil dan peningkatan kapasitas untuk mengelola kawasan konservasi perairan Pulau AyRhun. Kedua, kurangnya pemahaman terkait konservasi dengan nilai 0,6340 (sosial). Hal ini menunjukan bahwa tingkat pemahaman masyarakat masih sangat rendah terkait konservasi, khususnya masyarakat di Pulau Rhun.
Ketiga, adalah permasalahan ketidakstabilan harga jual hasil perikanan dengan nilai 0,5684 (ekonomi). Kondisi di lapangan menunjukkan bahwa hasil perikanan memiliki nilai jual yang sangat fluktuatif dan tidak menentu dibandingkan hasil perkebunan yang mengakibatkan mayoritas masyarakat bekerja sebagai petani. Keempat, penambangan pasir dan karang untuk bangunan dengan nilai 0,4614 (ekologi) menunjukkan masih terdapat banyaknya masyarakat yang menggunakan pasir dan karang sebagai bahan bangunan, sehingga menyebabkan beberapa titik di pulau mulai mengalami abrasi.

Kontribusi masing-masing elemen solusi pada setiap aspek dalam upaya menyusun prioritas kawasan konservasi perairan Pulau Ay-Rhun terdiri dari: 1) Optimalisasi pemanfaatan sesuai daya dukung dengan nilai 0,6137 (ekonomi); 2) pembentukan zonasi dengan nilai 0,5484 (ekologi); 3) penyusunan kebijakan pengelolaan dengan nilai 0,5308 (kelembagaan); dan 4) sosialisasi mengenai konservasi dengan nilai 0,4680 (sosial) (Gambar 8).

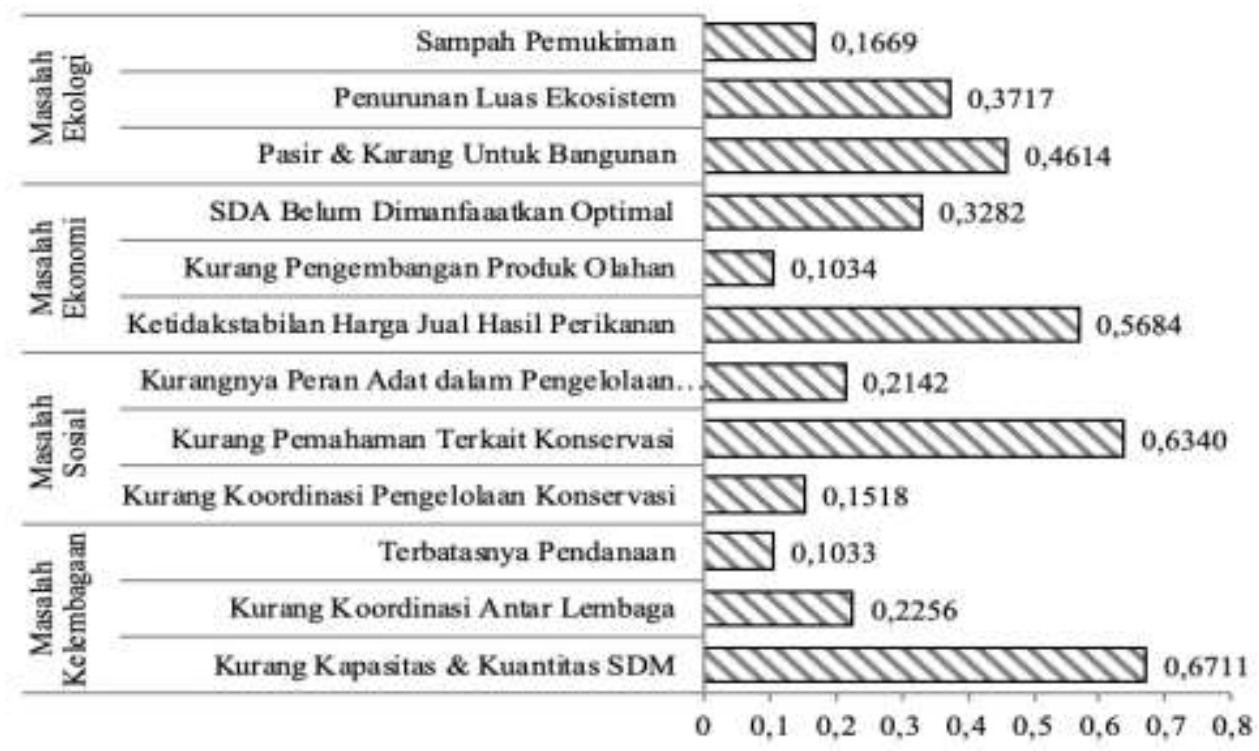

Gambar 7. Uraian masalah dalam upaya menyusun prioritas kawasan konservasi perairan Pulau Ay-Rhun. 


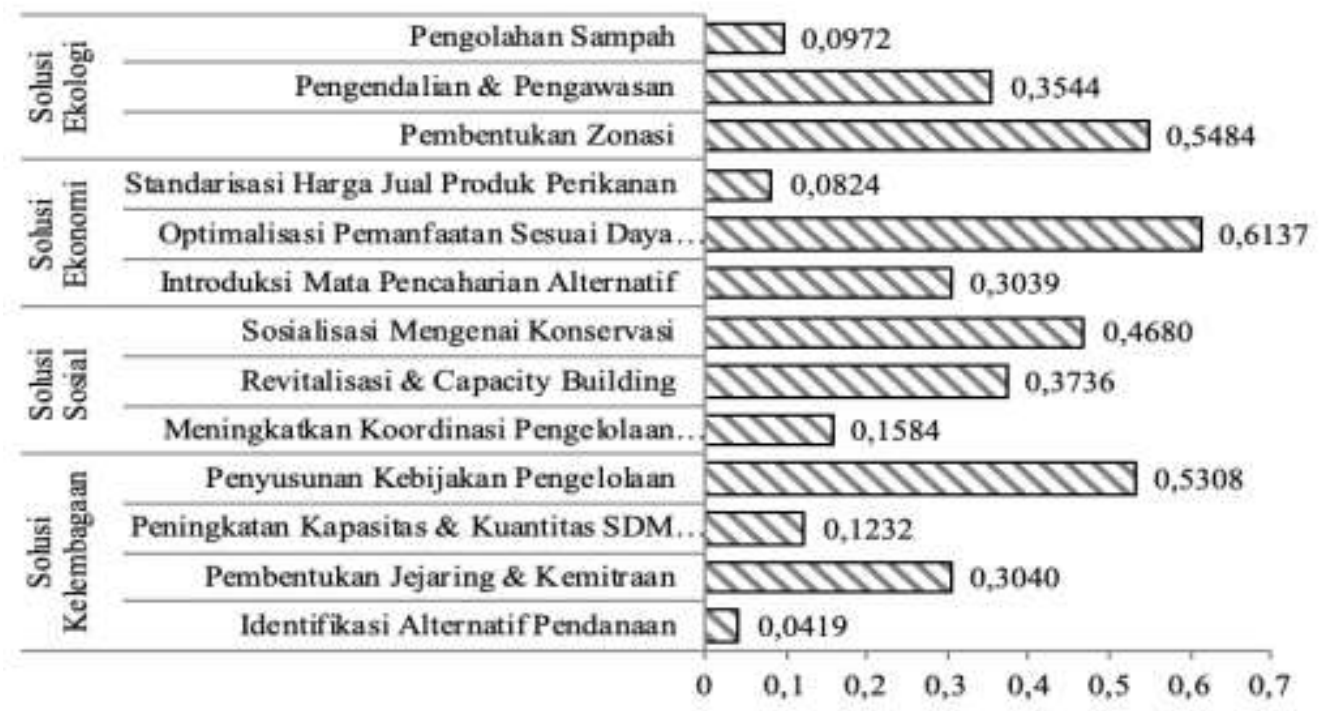

Gambar 8. Uraian solusi dalam upaya menyusun prioritas kawasan konservasi perairan Pulau Ay-Rhun.

Prasyarat penting dalam pe-nyusunan rencana pengelolaan adalah mengidentifikasi dan menentukan prioritas pengelolaan konservasinya. Seluruh solusi prioritas di dalam penelitian ini digunakan dengan pertimbangan bahwa seluruh prioritas yang dikaji memiliki keterkaitan dan pengaruh langsung atau tidak langsung. Desain prioritas pengelolaan yang dianalisis di atas untuk kawasan konservasi perairan Pulau Ay-Rhun telah memiliki kelembagaan lokal pengelola konservasi dan sudah sesuai dengan kerangka Design Principles of Resources Management (Ruddle, 1999). Tinjauan kritis adopsi kelembagaan lokal/adat dalam pengelolaan kawasan konservasi perairan sebagai sebuah unit manajemen dilakukan terhadap unsur-unsur sebagai berikut: (1) definisi batas sistem kawasan dan kawasan; (2) sistem hak bagi pengguna kawasan dan sumberdaya; (3) aturan main yang diterapkan bagi keberlanjutan kegiatan pemanfaatan kawasan dan sumberdaya; (4) sistem penegakan hukum bagi aturan main yang telah disepakati; (5) monitoring dan evaluasi bagi implementasi pengelolaan kawasan dan sumberdaya itu sendiri; (6) otoritas pengelolaan kawasan dan sumber-daya sebagai institusi yang bertanggung jawab terhadap proses dan mekanisme implementasi dari pengelolaan perikanan.

\section{KESIMPULAN}

Analytic Network Process (ANP) dapat digunakan dalam mengidentifikasi prioritas program perencanaan kawasan konservasi perairan Pulau Ay-Rhun melalui keterkaitan antar elemen yang dibagi ke dalam empat cluster (ekologi, ekonomi, sosial, dan kelembagaan). Prioritas perencanaan program pengelolaan kawasan konservasi perairan Pulau Ay-Rhun adalah empat program pengelolaan prioritas, yakni: (1) optimalisasi pe-manfaatan sesuai daya dukung; (2) pem-bentukan zonasi; (3) penyusunan kebijakan pengelolaan; dan (4) sosialisasi mengenai konservasi. Prioritas pengelolaan harus diperhatikan secara menyeluruh ber-dasarkan solusi yang diperoleh. Pengelolaan suatu kawasan konservasi perairan memerlukan koordinasi, dan kerjasama antar stakeholder di dalam kawasan konservasi perairan Pulau AyRhun. Prioritas tersebut merupakan titik krusial keberhasilan pencapaian tujuan dan sasaran konservasi untuk meningkatkan 
efektivitas pengelolaan melalui program prioritas yang terukur dan diimplementasikan terhadap sebuah kawasan konservasi.

\section{UCAPAN TERIMA KASIH}

Penelitian ini disponsori oleh Badan Pengembangan Riset dan Sumberdaya Kelautan dan Perikanan (BPRSDMKP) dan Coral Triangle Center (CTC). Ucapan terima kasih kepada Ibu Rili Djohani dan tim CTC atas bantuan di lapangan serta Dr. James Abrahamsz (Unpatti), Amehr hakim (KKP), Abdul Haris (DKP Provinsi Maluku) dan Mad Korebima (CTC) atas diskusi, saran dan masukannya.

\section{DAFTAR PUSTAKA}

Agardy, T. 1998. Global trends in marine protected areas. in: Sain et al. (eds). Prosiding Trends and future challenges for U.S. National ocean and coastal policy. Trends in managing the environment, University of Illinois, Amerika, 1999. 51-55 p.

Agardy, T., G.N. di Sciara, dan P. Christie. 2011. Mind the gap: addressing the shortcomings of marine protected areas through large scale marine spatial planning. Marine Policy, 35(2): 226-232.

https://doi.org/10.1016/j.marpol.2010. 10.006

Angulo-Valdés, J.A. and B.G. Hatcher. 2010. A new typology of benefits derived from marine protected areas. Marine Policy, 34: 635-44.

https://doi.org/10.1016/j.marpol.2009. 12.002

Ascarya. 2010. The development of islamic financial system in indonesia and the way forward. Occasional paper No. OP/10/02. Bank Indonesia. Indonesia.

Ascarya. 2011. The persistence of low profit and loss sharing financing in Islamic banking: the case of Indonesia review of Indonesian economic and business studies. Dalam: Hassan, K. The International Islamic Finance Conference 2013, Park Hyatt, Abu Dhabi, 14-16 April 2013.

Barnes, M.D., I.D Craigie, N. Dudley, and M. Hockings. 2016. Understanding local-scale drivers of biodiversity outcomes in terrestrial protected areas. Annuals of the New York Academy of Science, 1399(1): 42-60. https://doi.org/10.1111/nyas.13154

Cleguer, C., A. Grech, C. Garrigue, dan H. Marsh. 2015. Spatial mismatch between marine protected areas and dugongs in New Caledonia. Biol. Conserv., 184(1): 154-162. https://doi.org/10.1016/j.biocon.2015. 01.007

Cook, C.N., G. Wardell-Johnson, R.W. Carter, and M. Hockings. 2014. How accurate is the local ecological knowledge of protected area practitioners? Ecol. and Soc., 19(2): 32p. http://doi.org/10.5751/ES06341-190232

Edgar, G.J., R.D. Stuart-Smith, T.J. Willis, S. Kininmonth, S.C. Baker, S. Banks, N.S. Barrett, M.A. Becerro, A.T.F. Bernard, J. Berkhout, C.D. Buxton, S.J. Campbell, A.T. Cooper, M. Davey, S.C. Edgar, G. Försterra, D.E. Galván, A.J. Irigoyen, D.J. Kushner, R. Moura, P.Ed Parnel, N.T. Shears, G. Soler, E.M.A Strain, and R.J. Thomson. 2014. Global conservation outcomes depend on marine protected areas with five key features. Nature, 506: 216-220.

https://www.nature.com/articles/natur e13022

De Santo, E.M. 2013. Missing marine protected area (MPA) targets: how the push for quantity over quality undermines sustainability and social justice. J. of Environ. Manag., 124: 137-146. 
https://doi.org/10.1016/j.jenvman.201 3.01 .033

Fox, H.E., M.B. Mascia, X. Basurto, A. Costa, L. Glew, D. Heinemann, L.B. Karrer, S.E. Lester, A.V. Lombana, R.S. Pomeroy, C.S. Recchia, C.M. Robert, J.N. Sanchirico, L. Pet-Soede, and A.T. White. 2012. Reexamining the science of marine protected areas: linking knowledge to action. Conservation Letter, 5(1): 1-10. https://doi.org/10.1111/j.1755263X.2011.00207.x

Pemerintah Daerah Provinsi Maluku. 2016. Surat Keputusan Gubernur Maluku Nomor 388 Tahun 2016 tentang Pencadangan Kawasan Konservasi Perairan Pulau Ay-Pulau Rhun, Kecamatan Banda tengah, Provinsi Maluku.

Mittermeier, R.A., I.A. Bowles, dan R.B. Cavalcanti. 1995. A participatory approach to biodiversity conservation: the regional priority setting workshop. Conservation International. Washington. $16 \mathrm{p}$.

Marine Protected Areas News. 2012. Paper Parks Are-Examined: Building a Future for "MPAs-in-Waiting". International News and analysis on marine protected areas, 13(4): 8p.

Pomeroy, R.S., J.E. Parks, and L.M. Watson. 2004. How is Your MPA Doing? A Guidebook of Natural and Social Indicators for Evaluating Marine Protected Area Management Effectiveness. IUCN. Cambridge. 216 p.
Rodríguez-Rodríguez, D., S.E. Rees, L.D. Rodwell, and M.J. Attril. 2015. Assessing the socioeconomic effects of multiple-use MPAs in a European setting: a national stakeholders' perspective. Environmental. Science \& Policy, 48: 115-127. https://doi.org/10.1016/j.envsci.2014. 12.020

Ruddle, K. 1996. Boundary definition as a basic design principle of traditional fishery management system in Pacific Islands. Geographische Zeitschrift, 84: 94-102.

Rusydiana, A.S. dan A. Devi. 2013. Analytic network process: pengantar teori dan aplikasi. SMART Publishing. Bogor. $99 \mathrm{p}$.

Saaty, T.L. 2005. Theory and applications of the analytic network process: decision making with benefits, opportunities, costs, and risks. RWS Publications. Pittsburgh. 352 p.

Saaty, T.L. and L.G. Vargas. 2006. Decision making with the analytic network process. economic, political, social and technological applications with benefits, opportunities, costs and risks. RWS Publications. Pittsburgh. 278 p.

Susanto, H.A., S.S. Suraji, and M. Tokeshi. 2015. Management of coral reef ecosystems in Indonesia: past, present and the future. Coastal Ecosystem, 2: 21-41.

$\begin{array}{ll}\text { Received } & : 24 \text { April } 2019 \\ \text { Reviewed } & : 24 \text { May } 2019 \\ \text { Accepted } & : \text { :05 December } 2019\end{array}$


